\title{
Chemical and Sensory Parameters of Heat-treated Vacuum-packaged Broiler and Hen Fillet Products
}

\author{
Kristine Ramane*, Envija Strautniece, Ruta Galoburda \\ Department of Food Technology, LLU
}

\begin{abstract}
The heat treatment of vacuum-packaged products - Sous vide processing method - that offers convenience and storage stability, combined with poultry meat marinating was used in the current study. The aim of this research was to evaluate the effect of a fruit-vegetable additive on chemical and sensory parameters of heat-treated vacuum-packaged poultry meat products made from broiler or hen fillets. The skinless fillets and other ingredients were packaged in polyamide/polyethylene (PA/PE) pouches, vacuum sealed, marinated, heat treated, and chilled rapidly. The following parameters were evaluated: moisture content (LVS ISO 1442:197), protein content (LVS ISO 937:1978), fat content (LVS ISO 1443:1973), ash content (ISO 936:996), degree of liking, and intensity of sensory properties (ISO 4121:2003).The smallest changes in moisture content among the studied samples were observed in those prepared with the fruit-vegetable additive if compared to a raw fillet. In the process of heat treatment, the protein content in dry matter of broiler and hen fillet decreased $(p<0.05)$, whereas fat content decreased in broiler fillet but increased in hen fillet $(p<0.05)$. Sensory evaluation results showed that panellists preferred broiler fillet (6.6) and hen fillet (5.8) products which were prepared without the fruit-vegetable additive. Evaluation of the intensity of sensory properties showed that there do not exist significant differences in aroma, colour, flavour, and aftertaste of heat-treated vacuum-packaged hen and broiler fillet $(p>0.05)$, but texture of broiler fillet products is more tender than texture of samples made from hen fillet.
\end{abstract}

Key words: broiler, hen, fillet, fruit-vegetable additive.

\section{Introduction}

Research on poultry meat has indicated that tenderness, juiciness, taste and flavour of meat products are the main characteristics affecting consumer's satisfaction. These characteristics are influenced both by production factors (genetics, feeding systems, etc.) and processing techniques (chilling, marinating, and cooking) (Barbanti, Pasquini, 2004). Generally, increase in bird age is accompanied by an increase in meat toughness due to the higher collagen content in the muscle (Lee, Min et al., 2002). The improvement of tenderness of meats is mainly caused by changes in the structure of connective tissues solubilised by heat, while at the same time heat denaturation of myofibrillar proteins generally causes meats toughening (Palka, Daun, 1999).

It is critical for food industry to develop techniques for production of poultry meat products meeting consumer expectations, additionally providing convenience and extended shelf-life.
Varied modern technologies could be used in order to achieve this goal, including the heat treatment of vacuum-packaged products - Sous vide technology. It was developed in France in mid-70s of the 20th century (Creed, Reeve, 1998). This technology is based mainly on thermal processing of a vacuum-packaged product at the temperature of $65-95{ }^{\circ} \mathrm{C}$ and its storage in a chilled condition $\left(1\right.$ to $4{ }^{\circ} \mathrm{C}$ ). Duration of the heat treatment process is chosen to ensure pasteurization effect that reduces considerably the count of microorganisms and prolongs the storage time as a result. However, the commercial sterility of the product is not ensured by this process. At choosing thermal processing regimes (temperature-time) for protein-rich products there is often a tendency to set forward the task of preserving the quality of a product as the primary, a lesser weight giving to inactivation of microorganisms, which being related to product safety reduces the shelf life (Gonzalez-Fandos, Villarino-Rodríguez et al., 2005).

During the research on food consumption in the population of Latvia (2007-2009), the 
detected nutrient proportions revealed a bit higher consumption of proteins, which is mainly caused by an excessive use of food products of animal origin. Therefore it would be beneficial to develop new products made from ingredients both of animal and lant origin.

Marination in a traditional culinary technique is used to increase water binding ability of meats thus reducing cooking losses, to tenderize meat, and to improve juiciness (Froning, Sackett, 1985; Quiao, Fletcher et al., 2002; Brabanti, Pasquini, 2005). Marination has become increasingly popular in modern cooking, especially when cooking pork and poultry. Marination has two effects: dissolves some of the support structures of the muscle fibers so they cannot coagulate into dense aggregates, and allows the meat to absorb between $10-25 \%$ of its weight in water (which may include aromatics from herbs and spices) (McGee, 2004; Graiver, Pinotti et al., 2006). While the meat will still lose around $20 \%$ of its weight when cooked, the net effect will be a loss of only about $0-12 \%$ of its original weight.

Combination of the two above-described methods - marination and heat treatment of vacuumpackaged fillets - would allow obtaining convenient products with extended shelf life. In order to enhance nutritional value of the product, a fruit-vegetable additive can be used (Dukalska, Ramane et al., 2010). The aim of the present research was to evaluate the effect of a fruit-vegetable additive on chemical and sensory parameters of heat-treated vacuumpackaged poultry meat products made from broiler or hen fillet.

\section{Materials and Methods}

Chilled skinless broiler and hen fillets were cut in 20-35-mm-thick slices perpendicular to the muscle fibres, mixed with salt, dried dill and parsley, crushed garlic, and wine. Seasoned fillet samples of $130 \pm 10 \mathrm{~g}$ were inserted into a package, and $12 \mathrm{~mL}$ of white wine were added. For half of the samples, $65 \mathrm{~g}$ of a mixture of sea buckthorn sauce and shredded carrots were added (further in the text - fruit-vegetable additive). The composition of sea buckthorn sauce included apple puree, sea buckthorn puree, carrots, as well as spices, salt, sugar, and garlic. The prepared fillet samples were vacuum-packaged in polyamide/ polyethylene (PA/PE) pouches (film thickness $90 \mu \mathrm{m}$, pouch size $-230 \times 145 \mathrm{~mm}$ ). The packaged products were placed in Elcold cooling camera for 20-24 hours at the temperature of $3.0 \pm 0.5{ }^{\circ} \mathrm{C}$.
Afterwards, the marinated products were thermally treated in a water bath at the temperature of $80.0 \pm 1.0^{\circ} \mathrm{C}$ (broiler fillet for $30 \mathrm{~min}$, hen fillet for $40 \mathrm{~min}$ ), which ensures product readiness for use and microbiological safety. After heat treatment, the samples were cooled in a water-ice bath and stored at $+3.0 \pm 0.5{ }^{\circ} \mathrm{C}$ until analyzing. The technology used for fillet preparation is described in the Patent of the Republic of Latvia, No. 14095 (Dukalska, Ramane et al., 2010). Chemical and sensory parameters were determined on the 12th day of storage.

Poultry meat was purchased from the largest poultry meat producer in Latvia. Spices, white wine, carrots and garlic were purchased at retail. Sea buckthorn sauce was prepared and supplied from the Latvia State Institute of Fruit-Growing in Dobele.

The following samples of broiler and hen fillet products were subjected to chemical and sensory evaluation:

A - hen fillet without fruit-vegetable additive;

$\mathrm{B}$ - hen fillet with fruit-vegetable additive;

$\mathrm{C}$ - broiler fillet without fruit-vegetable additive;

D - broiler fillet with fruit-vegetable additive.

Chemical composition of poultry meat was analysed in triplicate at the Institute of Food Safety, Animal Health and Environment „BIOR” using the following methods: moisture content by the method LVS ISO 1442:197, protein content by the Kjeldahl method LVS ISO 937:1978, fat content by the Soxhlet method LVS ISO 1443:1973, and ash content by the method ISO 936:1996 using a muffle furnace.

Sensory evaluation was performed in the Laboratory of Sensory Evaluation at the Faculty of Food Technology of the Latvia University of Agriculture in March 2010. All meat samples were evaluated by twenty five panellists $(10$ men and 15 women, mean age - 23). The samples were removed from the refrigerator, cut and served for evaluation.

The intensity of sensory properties (aroma, colour, flavour, and aftertaste) was evaluated using line scale, but the degree of liking was evaluated by nine-point hedonic scale (ISO 4121:2003). In order to evaluate the perceived intensity of poultry meat products, the panellists were asked to note intensity of the following sensory attributes: aroma (weak very strong), colour (light greyish - greyish), flavour (weak - very strong), texture (tender - tough), and aftertaste (weak - very strong). The obtained data was averaged across panellists. Hedonic scale includes 9 
points, which allows evaluating the degree of liking. The points are from "like very much" (9) to "dislike very much" (1) and the middle point is "neither like nor dislike" (5).

The obtained results were analysed using analysis of variance (ANOVA). Tukey's test was applied when significant differences among the heat-treated vacuum-packaged samples were found.

\section{Results and Discussions}

The chemical composition of raw and vacuum packaged, heat treated products made from breast meat of broiler and hen are presented in Table 1. The content of moisture after heat treatment in broiler fillet without additive decreased for $8.86 \%$. The content of moisture after heat treatment in hen fillet without additive decreased for $9.98 \%$. According to research by Chiavaro, Rinaldi et al. (2009), during the heat treatment of meat, denaturation of miofibrillar proteins takes place that changes the water binding ability in meat. As a result of shrinkage of proteins, the miofibrillar space reduces, and the water from it is forced into outer environment. Our results show that the most significant $(p<0.05)$ changes in moisture content were observed in samples which were heat-treated without the fruit-vegetable additive if compared to the raw product. The study proved that meat moisture content was reduced in all studied samples in the result of heat treatment process $(p<0.05)$.

In the process of heat treatment, the fat and protein content in the dry matter of broiler fillet decreased, whereas in hen fillet the fat content increased and protein content decreased. It can be explained by a significantly different quantitative and qualitative composition of fatty and amino acids in broiler and hen fillets, which can influence solubility and heat stability of proteins and fats. Hunt, Lewis et al. (1999) have observed that due to the moisture loss the concentration of many nutrients increased during cooking despite partial destruction of certain heat labile nutrients and nutrient loss in the drained juices.

Hedonic evaluation scores of the new developed broiler and hen fillet (musculus pectoralis major) products with/without fruit-vegetable additive are summarized in Figure 1. The analysis of variance (ANOVA) allows concluding that there were significant differences among the samples under research $\left(\mathrm{F}_{\text {apr. }}=6.28>\mathrm{F}_{p<0.05}=2.73\right)$; for further analysis Tukey's test was used in order to determine differences among the various samples.

The results of hedonic scores showed that panellists had preferred $(p<0.05)$ broiler and hen fillet products without fruit-vegetable additive. Analysis indicated no significant differences in hedonic scores between samples A and C ( $>00.05)$. The sample B did not differ from sample $D$, whereas sample $C$ differed considerably $(p<0.05)$ from samples B and D.

Evaluation of the intensity of sensory properties showed that there were no significant differences $(p>0.05)$ in aroma, colour, taste and aftertaste among the heat-treated vacuum-packaged broiler and hen fillet products; however, the texture of heattreated vacuum-packaged broiler fillet products was softer $(p<0.05)$ than texture of hen fillet products (Table 2). Sensory evaluation of product

Table 1

Chemical composition ( \pm standard deviation) of raw and heat-treated vacuum-packaged poultry meat samples, $\mathrm{g}^{100} \mathrm{~g}^{-1}$

\begin{tabular}{|c|c|c|c|c|c|}
\hline \multicolumn{2}{|c|}{ Sample description } & Water & Protein & Fat & Ash \\
\hline \multirow{3}{*}{ Broiler fillet } & chilled & $74.30 \pm 0.30^{\mathrm{a}}$ & $22.85 \pm 0.29^{\mathrm{a}}$ & $1.70 \pm 0.10^{\mathrm{a}}$ & $1.15 \pm 0.01^{\mathrm{a}}$ \\
\hline & $\begin{array}{l}\text { heat-treated } \\
\text { without additive }\end{array}$ & $69.51 \pm 0.30^{\mathrm{b}}$ & $25.98 \pm 0.10^{\mathrm{b}}$ & $1.79 \pm 0.20^{\mathrm{b}}$ & $2.32 \pm 0.02^{\mathrm{b}}$ \\
\hline & $\begin{array}{l}\text { heat-treated } \\
\text { with additive }\end{array}$ & $71.06 \pm 0.30^{c}$ & $25.13 \pm 0.22^{c}$ & $1.59 \pm 0.10^{\mathrm{c}}$ & $1.82 \pm 0.02^{\mathrm{c}}$ \\
\hline \multirow{3}{*}{ Hen fillet } & chilled & $72.20 \pm 0.30^{\mathrm{d}}$ & $25.05 \pm 0.30^{\mathrm{c}}$ & $1.60 \pm 0.20^{\mathrm{c}}$ & $1.15 \pm 0.01^{\mathrm{a}}$ \\
\hline & $\begin{array}{l}\text { heat-treated } \\
\text { without additive }\end{array}$ & $66.93 \pm 0.30^{\mathrm{e}}$ & $28.69 \pm 0.20^{\mathrm{d}}$ & $1.92 \pm 0.10^{\mathrm{d}}$ & $2.06 \pm 0.02^{\mathrm{d}}$ \\
\hline & $\begin{array}{l}\text { heat-treated } \\
\text { with additive }\end{array}$ & $68.49 \pm 0.30^{f}$ & $27.42 \pm 0.14^{\mathrm{e}}$ & $1.87 \pm 0.10^{\mathrm{e}}$ & $1.87 \pm 0.03^{\mathrm{c}}$ \\
\hline
\end{tabular}

Note. Samples with the same letter superscripts within a column do not differ significantly $(p>0.05)$. 


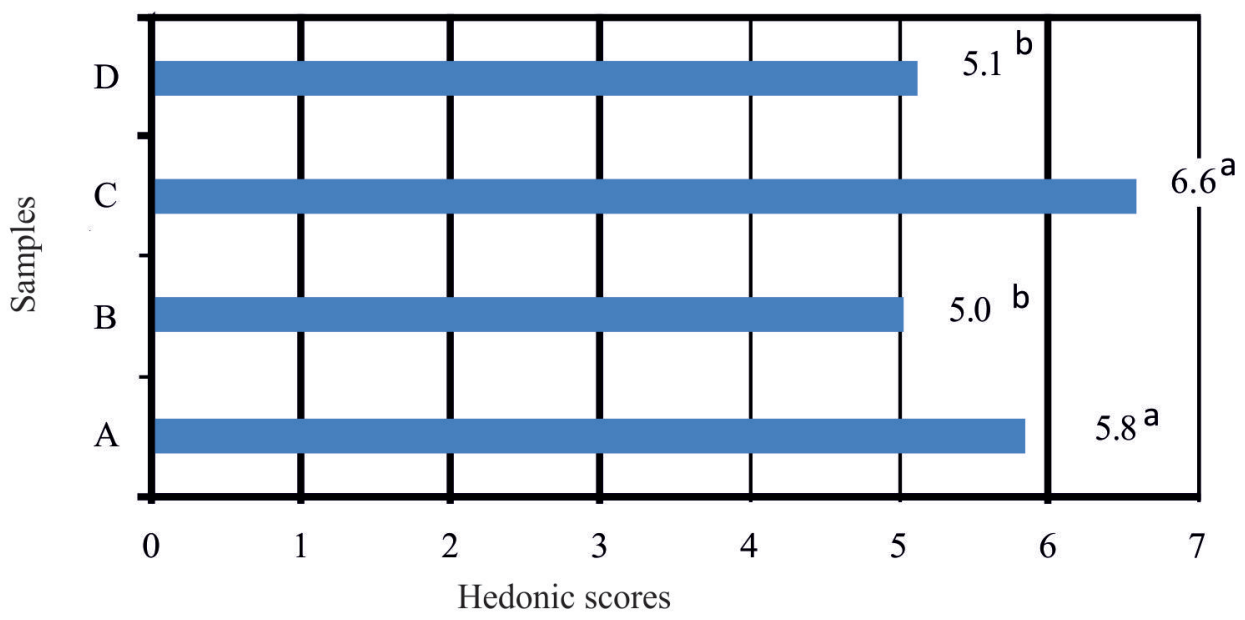

Note. Samples with the same letter superscripts do not differ significantly $(p>0.05)$.

Fig. 1. Degree of liking for the four poultry meat product samples:

A - hen fillet without fruit-vegetable additive; $\mathrm{B}$ - hen fillet with fruit-vegetable additive;

$\mathrm{C}$ - broiler fillet without fruit-vegetable additive; D - broiler fillet with fruit-vegetable additive.

Table 2

Intensity of sensory properties of the studied samples

\begin{tabular}{|c|c|c|c|c|c|}
\hline \multirow{2}{*}{ Description of sensory properties } & \multicolumn{4}{|c|}{ Samples* } & \multirow{2}{*}{$p_{0.05}$} \\
\hline & $\mathrm{A}$ & $\mathrm{B}$ & $\mathrm{C}$ & $\mathrm{D}$ & \\
\hline Aroma: weak - very strong & $5.0^{\mathrm{a}}$ & $5.3^{\mathrm{a}}$ & $5.2^{\mathrm{a}}$ & $5.3^{\mathrm{a}}$ & 0.961 \\
\hline Colour: light greyish - greyish & $3.8^{\mathrm{a}}$ & $4.1^{\mathrm{a}}$ & $3.4^{\mathrm{a}}$ & $4.5^{\mathrm{a}}$ & 0.365 \\
\hline Flavour: weak - very strong & $6.0^{\mathrm{a}}$ & $5.0^{\mathrm{a}}$ & $5.8^{\mathrm{a}}$ & $5.7^{\mathrm{a}}$ & 0.324 \\
\hline Texture: tender - tough & $2.5^{\mathrm{b}}$ & $3.0^{\mathrm{b}}$ & $6.9^{\mathrm{a}}$ & $7.6^{\mathrm{a}}$ & 0.000 \\
\hline Aftertaste: weak - very strong & $6.3^{\mathrm{a}}$ & $6.4^{\mathrm{a}}$ & $5.5^{\mathrm{a}}$ & $6.2^{\mathrm{a}}$ & 0.331 \\
\hline
\end{tabular}

* - Sample descriptions see in Fig. 1.

Note. Samples with the same letter superscripts do not differ significantly $(p>0.05)$.

texture confirmed our previous results obtained by instrumental measurement which showed that broiler fillet samples were tenderer than hen fillet samples (Ramane, Galoburda et al., 2010). This coincides with other researchers' data that indicate the influence of bird age on the toughness of meat (Chen, Ma et al., 2007).

There was no significant difference established in texture between samples C and D. It allows concluding that the fruit-vegetable additive does not influence the texture of broiler and hen fillet.

\section{Conclusions}

The smallest $(p<0.05)$ changes in the moisture content of the studied samples were observed in those prepared with the fruit-vegetable additive if compared to a raw product. In the process of heat treatment the fat and protein content in the dry matter of broiler fillet decreased $(p<0.05)$, whereas in hen fillet the fat content increased and protein content decreased $(p<0.05)$ due to different solubility of above-mentioned components in the juice drained from the meat.

Sensory evaluation showed that panellists preferred heat-treated vacuum-packaged broiler fillet (6.6) and hen fillet (5.8) products which were prepared without the fruit-vegetable additive.

Evaluation of the intensity of sensory properties indicated that there were no significant differences $(p>0.05)$ in aroma, colour, flavour and aftertaste of cooked hen and broiler fillets, whereas texture of broiler fillet products was more tender $(p<0.05)$ than texture of hen fillet products. It agrees with our previous studies demonstrating the influence of bird age on meat tenderness. 


\section{References}

1. Barbanti, D., \& Pasquini, M. (2005). Influence of cooking conditions on cooking loss and tenderness of raw and marinated chicken breast meat. LWT - Food Science and Technology, 38, 895-901.

2. Chen, X. D., Ma, Q. G., Tang, M. Y., \& Ji, C. (2007). Development of breast muscle and meat quality in Arbor Acres broilers, Jingxing 100 crossbred chickens and Beijing fatty chickens. Meat Science, 77(2), 220-227.

3. Chiavaro, E., Rinaldi, M., Vittadini, E., \& Barbanti, D. (2009). Cooking of pork Longissimus dorsi at different temperature and relative humidity values: effects on selected physico-chemical properties. Journal of Food Engineering, 93, 158-165.

4. Creed, P.G., \& Reeve, W. (1998). Principles and applications of sous vide processed foods. In G. Ghazala (Ed.), Sous vide and cookchill processing for food industry (pp. 25-56). Gaithersburg, Maryland: Aspen Publishers, Inc.

5. Dukalska, L., Ramane, K., Galoburda, R., \& Seglina, D. (2010). Patent of Republic of Latvia No. 14095. Rīga: Latvija. Latvijas Republikas Patentu valde.

6. Froning, G. W., \& Sackett, B. (1985). Effect of salt and phosphates during tumbling of turkey breast muscle on meat characteristics. Poultry Science, 64, 1328-1333.

7. González-Fandos, E., Villarino-Rodríguez, A., García-Linares, M. C., García-Arias, M. T., \& García-Fernández, M. C. (2005). Microbiological safety and sensory characteristics of salmon slices processed by the sous vide method. Food Control, 16, 77-85.
8. Graiver, N., Pinotti, A., Califano, A., \& Zaritzky, N. (2006). Diffusion of sodium chloride in pork tissue. Journal of Food Engineering, 77, 910-918.

9. Hunt, A., Lewis, J., Milligan, G., \& Deeps, K. (1999). Nutrient composition of Australian chicken. Australia New Zealand Food Authority, ACT. In The Eleventh Australian Poultry \& Feed Convention on October, 1999. Retrieved from http://www.chicken.org.au/page. php?id=10

10. Lee, S. O., Min, J. S., Kim, I. S., \& Lee, M. (2002). Physical evaluation of popped cereal snacks with spent hen meat. Meat Science, 64, 383-390.

11. McGee, H. (2004). On Food and Cooking: the Science and Lore of the Kitchen. New York: Scribner.

12. Palka, K., \& Daun, H. (1999). Changes in texture, cooking losses, and myofibrillar structure of bovine $M$. Semitendinosus during heating. Meat Science, 51, 237-243.

13. Quiao, M., Fletcher, D. L., Smith, D. P., \& Northcutt, J. K. (2002). Effects of raw broiler breast meat color variation on marination and cooked meat quality. Poultry Science, 81, 276-280.

14. Ramane, K., Galoburda, R., Murniece, I., \& Dukalska, L. (2010) Physical-chemical evaluation of sous vide cooked parents stock hen breast meat during refrigerated storage. In Research for Rural Development 2010: Annual 16th International scientific conference, Jelgava, 19-21 May 2010, Vol. 1 (pp. 159162). Jelgava, Latvia: Latvia University of Agriculture.

\section{Acknowledgements}

The research was supported by ESF grant (contract No. 04.4-08/EF2.D3.21.). 